\title{
Ship-Generated Waste and Cargo Residues Institutional Framework and Management in Albania
}

Erjola Keçi

\author{
Lecturer at Aleksandër Moisiu University, Faculty of Professional Studies, Durrës, Albania
}

Osman Metalla

Dean of Aleksandër Moisiu University, Faculty of Professional Studies, Durrës, Albania

\section{Doi:10.5901/ajis.2016.v5n3s1p368}

\begin{abstract}
Approximation of the Acquis into national legislation is an iterative process involving institutional arrangements and adoption of specific binding legal measures (quality and technical standards, testing and notification requirements, etc.) and countryspecific decisions on discretionary and suggested legal measures. Having the candidate status to EU entrance and being a costal country Albania has to handle important issues as water quality and management and other issues linked with. The Directive on port reception facilities for ship-generated waste and cargo residues ${ }^{1}$ pursues the same aim as the MARPOL Convention $73 / 78^{2}$ on the prevention of pollution by ships, which Albania has signed and ratified, and the Ballast Water Management Convention: to reduce discharges of ship-generated waste and cargo residues into the sea. The Directive focuses on ship operations in European Union ports obliging ports' authorities to establish adequate reception facilities and to require that ships using these facilities, while the MARPOL Convention regulates discharges by ships at sea. The Directive addresses in detail the legal, financial and practical responsibilities of the different operators involved in delivery of shipgenerated waste and cargo residues. The present article presents the approximation process consisting of legal transposition, practical implementation, and enforcement of the EU Directive 2000/59/EC in Albania.
\end{abstract}

Keywords: Ship-generated waste, Cargo residues, Directive transposition, Transposition Plan

\section{Introduction}

The Directive focuses on ship operations in European Union harbours obliging ports to establish adequate reception facilities and to require that ships use these facilities, while the MARPOL Convention regulates discharges by ships at sea. The Directive addresses in detail the legal, financial and practical responsibilities of the different operators involved in delivery of ship-generated waste and cargo residues.

Member States must ensure that port reception facilities are provided which meet the needs of the ships using them without causing abnormal delays. These facilities must be tailored to the size of the port and to the categories of ship calling there.

A waste reception and handling plan must be drawn up in each port according to the Annex I of the Directive. These plans must be approved and assessed by the Member State it relates to. The plans must be reviewed and reapproved at least every three years.

Before entering a port the ship has to notify the port authorities about the date and the last port in which shipgenerated waste was delivered and the quantity of waste remaining on board.

Ships are required to deliver their ship-generated waste before leaving a Community port, unless the captain can prove that his vessel has adequate storage capacity until entering the next port.

Ships which do not deliver their waste and has no valid reasons for exemption are not allowed to leave the port

\footnotetext{
1 Directive 2000/59/EC of the European Parliament and of the Council of 27 November 2000 on port reception facilities for shipgenerated waste and cargo residues, as amended by Directive 2002/84/EC of the European Parliament and of the Council of 5 November 2002, Commission Directive 2007/71/EC of 13 December 2007 and Regulation (EC) No 1137/2008 of the European Parliament and of the Council of 22 October 2008

2 International Convention for the Prevention of Pollution from Ships, 1973 as modified by the Protocol of 1978.
} 
until such delivery has taken place.

Ships calling at a port pay a fee covering a proportional and significant part of the cost of the waste reception and handling facilities whether they use the facilities or not.

Ships operating in an Albanian port may be inspected. The directive specifies a $25 \%$ minimum inspection requirement.

The current state-of-play with regard to Maritime Pollution in Albania calls for the establishment of an efficient ship waste handling system designed to ensure proper waste management services in compliance with national and international legislation. In our assessment of the situation the key issues are as follows:

1. Albania has a coastline of about $476 \mathrm{~km}$, the Adriatic Sea in the north and the Ionian Sea in the south. These coasts are particularly vulnerable for the sea water being polluted by illegal discharges from ships, as well as by oil spills from vessels.

2. The Albanian authorities recognise these dangers and have developed legislation and policies that serves to minimize the risks of sea and costal pollution with oil and other dangerous substances.

3. Albania has made considerable progress in aligning maritime pollution prevention and control legislation and policies to meet international and EU requirements. The works on establishment of national system for waste reception from ships in the Albanian ports and sea areas has been started after Albania became State party to MARPOL Convention, and several ports have established their own waste reception facilities.

4. However, despite the progresses, some challenges exist in relation to illegal discharges from ships to sea, and disharmonies and challenges continue between practical application of procedures and requirements from legislation. Indeed significant efforts are needed to implement the legislation, and significant strengthening of administrative capacity, both at central and local level, is of the utmost importance.

5. Port's waste management needs to be addressed in an integrated and systematic way to ensure not only an environmental protection or a viable economic infrastructure but also acceptable operational methods to fulfil the international requirements.

6. Some reception facilities for ship generated waste are available in Albanian ports, but they need to be improved and increased for the ports to handle the ship generated waste in the future when ships will be required to deliver their ship-generated waste in line with the requirements of the EU Directives 2000/59/EC.

7. There is the clear need to overcome the weaknesses and deficiencies of the current system of marine pollution prevention and control by:

- Strengthening of existing technical and administrative capacity for the implementation of international agreements and EU Directives 2000/59/EC.

- Preparing and implementing an adequate planning system and sectorial strategies.

- Preventing potential effects of ships' ballast sediments and disposal of these sediments at ports reception facilities.

- Designing and putting in place of additional measures to minimise ship generated waste.

- Increasing of awareness among local and central stakeholders (industrialists, farmers, tourism sector, general public etc.), primarily those from the private sector.

- Developing waste reception and management infrastructure.

The responsibilities over the implementation of the directive port reception facilities for ship-generated waste and cargo residues (competent authorities) lies within the Ministry of Infrastructure and Transportation (MolT) and the Ministry of Environment (MoE). These Ministries are the main competent authorities to implement the Ship Generated Waste regulatory framework in Albania.

The MoE is responsible for issuing the environmental permits as well as for monitoring and enforcement of the environment legislation and authorisation of the waste managing companies, while the MolT is the overall responsible for maritime policy with its Department of Maritime Transport Policy playing the important role in practical issues.

Under the mentioned Ministries, the specific state entities also have responsibilities for the implementation of the Port Reception Facilities for Ship-Generated Waste and Cargo Residues Directive. In Durres these are:

- General Maritime Directorate

- General Harbour Master's Office;

- Environment's Directory, Durres Port Authority;

- Coast Guard;

- Port Authority Durres (responsible for waste management plan and contracts with operators);

- Durres Harbour Master's Office (usually responsible for waste notification); 
- Port State Control (responsible for monitoring and enforcement), which comply with the Law no.9852, date 26.12.2007 "On accession of Republic of Albania in Paris Memorandum of Understanding "Port State Control" and in the next future provisions of the Port State Control Directive 95/21/EC;

The main stakeholders are waste operators (which are already contracted by the Port Authorities), currently Company "Garbage \& Sludge oil Collection Service" and Ship Enterprise for Maritime Service for issues related to the functioning of these institutions.

\subsection{Port facilities in Albania}

Maritime traffic in Albania is served by a port system that comprises the major ports of Durres and Vlore and the relatively smaller in terms of size and traffic, ports of Shengjin and Saranda. The Port of Durres handles the major part of the total volume of goods discharged from or loaded to ocean going ships.

In the present situation the Port of Durrës is congested and the Albanian Government has designated an area 10 $\mathrm{km}$ north of Durrës (Romano Port) to be the new location for the storage of oil products and liquefied petroleum gas (LPG). In 2008/2009 the Romano Port completed the civil/structural part of the port facilities required for loading and unloading LPG and oil.

The port of Durres located $40 \mathrm{~km}$ far from the capital town of Tirana handles the major part of Albania's international traffic (approximately 80\%). The port handles all kinds of goods including general cargo, dry bulk, breakbulk, containers, liquid bulk and dangerous cargo. There are regular passenger/cargo ferry services to Bari, Ancona and Trieste. The main imports are construction materials, construction steel, coal, wheat, cement. The main exports are oil, bitumen, chrome ore, iron-nickel ore, textiles and marble.

Vlore port is located $90 \mathrm{~km}$ south of Tirana represents a developing port with important fishing activities. The state managed port of Vlore is the second largest port of Albania situated at the Vlora Bay constituting an open harbour with two main quays and an anchorage. The port handles building material, cement, etc. mainly imported from the neighbouring Italy. It handles some $8 \%$ of the country's import and $11 \%$ of country's export tonnage, a total of $10 \%$ of Albania's traffic. Similarly to the Port of Durrës cargo traffic is quite unbalanced between imports equal to $94 \%$ of total throughput and exports at $6 \%$ of total throughputs. Vlore is the only harbour on the Adriatic coast with deepwater access within 250 metres of the shore and might replace Durrës as Albania's main gateway for trade. Durrës is closer to Tirana but needs constant dredging to serve the needs of ocean-going ships.

The port of Shengjin is located in the northern part of the country, some $60 \mathrm{kms}$ north of Durres, representing a commercial port basically engaged in handling of cement, building material, foodstuff, and petroleum products. Some $10 \%$ of the country's import and 4\% of country's export tonnage pass through the port, a total of $9 \%$ of Albania's traffic. Cargo traffic is quite unbalanced between imports equal to over $97 \%$ of total throughput and exports at $3 \%$ of total throughputs. The southernmost Port of Saranda has a total throughput of a few percent of the national cargo. No export cargoes are recorded. The port also handles a small amount of passenger traffic.

\section{Methodology}

The study has been carried out as follows:

1. Determination of the current level of concordance with the requirement of Directive 2000/59/EC using high level conceptual table of concordance. An overall gap analysis providing a critical review on the level of compliance (as a matter of law, administrative procedure and of practical implementation) between national legislation and practices, and what envisaged by EU requirements has been carried out. Albanian laws in the sub sector, institutions and procedures have been compared with the requirements of EU. The goal was to systematically review the key elements of the Directive, interpreting the legal requirements in terms of the practical measures required to achieve compliance, e.g., administrative structures, monitoring infrastructure, information management systems, technical requirements, etc. This analysis has also reviewed which state bodies hold responsibilities for specific requirements, and where responsibilities have not yet been defined.

2. Estimation of the administrative resources required for implementation of the legislation in the sub sector over the short, medium and long term including permitting and environmental monitoring. The main findings of the gap analysis have formed the basis for identifying and deciding on the required future implementation and enforcement actions. All steps, assumptions and judgements in an assessment of the administrative resources will be justified, simple and user-friendly, so as it may open to eventual challenges. The reasoning behind the 
estimation will be explicit and transparent.

3. Consideration of the resources and methods which will be needed to ensure implementation including communication, publicity, information management, inspection, surveillance, and enforcement. The objective was to analyse the practical situation of the administration and to estimate the resources needed on meeting the requirements of the directives and implementing the institutional and administrative actions for compliance. Practical experience from other EU countries have been also utilised when outlining of a national implementation plan.

\section{Results}

The full transposition of the Directive on port reception facilities for ship-generated waste and cargo residues has been achieved by adopting the DCM on "Approval of Regulation on port reception facilities and requirements on shipgenerated waste and cargo residues", the main responsibilities over the implementation of the Directive 2000/59/EC lies within the Ministry of Infrastructure and Transportation and the Ministry of Environment

The DCM introduces the following practical approach for the implementation of the Directive:

a. The direct fee regime shall be applied to all ships calling at an Albanian port, delivering deliver the ship generated waste as defined in the MARPOL 73/78 to the licensed waste operators and/or port reception facilities. These ships shall pay a fee for the services provided in order to obtain a waste delivery certificate from the licensed waste operators.

b. The indirect (fixed) fee regime shall be used in Albanian ports for those ships NOT delivering waste. The ships not delivering waste shall pay the indirect fee in order to contribute significantly to the costs of port reception facilities for ship-generated waste, irrespective of actual use of the facilities. The waste fee may be differentiated with respect to, inter alia, the category, type and size of the ship, according to the criteria defined in a table included in Annex III of the Regulation and possible instructions of the Minister to be developed.

c. The waste fee may be reduced if the ship's environmental management, design, equipment and operation are such that the master of the ship can demonstrate that it produces reduced quantities of ship-generated waste.

d. Concerning the responsibilities:

- The Port/port authority will collect the waste fees from the agent/ship.

- The Port/port authority will pay the waste operators for the waste collection services provided by the waste operators.

- The waste fee will be fixed by the Ministry of Infrastructure and Transportation on the basis of proposal put forward by the Port/port authority and following negotiations with the waste operators.

- A Port State Control unit under the Ministry of Infrastructure and Transportation will be responsible for inspection and enforcement.

- Information about notification, waste deliverance and the period where ships visit the port has to be shared between the Port/port authorities, the Port State Control unit and the competent authorities via a information and monitoring system (database) designed for the purpose and maintained by the Port/port authority.

The Directive requires that the user pay principle is employed when implementing the Directive. This means that there are limited running operating costs for the public sector in relation to the directive, if the cost/recovery principles are correctly applied. The main costs are related to a proposed Technical Assistance project with the purpose to draft the first generation of port waste handling and reception plans, elaborate proposals for ship generated waste fee, waste notification system, a contractual framework for waste operators, a waste fee invoicing system, inspection and enforcement procedures, a fee/tariff system for each of the ports based on a combination of a direct fee system and indirect/fixed fee system for the ships not delivering waste. Further the TA project shall establish appropriate information and monitoring system and train the human resources in the Ministry of Infrastructure and Transportation, Harbour Authorities and Port State Control.

\section{Conclusions}

Waste management planning and its implementation is an important economic, environmental, technical and administrative issue for the Albanian authorities. As in the case of ports, port waste management planning and its implications form a rapidly growing subject of interest in the costal management context. 
We recognise that effective implementation of MARPOL 73/78 and Directives 2000/59/EC in Albania requires an integrated approach to government administration that includes coordination mechanisms across governmental institutions, local responsibility and action ${ }^{3}$, public participation, and accountability of state and private institutions.

Regulations set by MARPOL (73/78) and especially the Directive 2000/59/EC of the European Parliament on port reception facilities for ship-generated waste and cargo residues already stipulate that ports should provide reception facilities for vessels to safely dispose and manage various types of wastes. National authorities, in order to be in compliance with related international agreements and EU Directives, must initiate a number of activities, including, but not limited to:

1. Availability of port reception facilities. Albania shall ensure the availability of port reception facilities adequate to meet the needs of the ships normally using the port without causing undue delay to ships. The works on establishment of national system for waste reception from ships in the Albanian ports and sea areas has been started after Albania became State party to MARPOL Convention. Many coastal facilities have established waste reception facilities following the requirements of current legislation.

2. Elaboration of waste reception and handling plans. Following consultations with port users and other relevant parties a waste reception and handling plan shall be developed and implemented for each port.

3. Notification. All ships, apart from state ships, warships, fishing vessels and small recreational crafts, are required to notify certain information, in particular the date and the last port in which ship-generated waste was delivered and the quantity of waste remaining on board.

4. Delivery of ship-generated waste. A ship shall, before leaving the port, deliver all ship-generated waste to a port reception facility unless there is adequate storage capacity for all ship-generated waste accumulated until the port of delivery and this port is equipped with appropriate reception facilities. Ships which do not deliver their waste without providing valid reasons for exemption, are not allowed to leave the port until such delivery has taken place.

5. Fees for ship-generated waste. The costs of port reception facilities for ship-generated waste, including the treatment and disposal of the waste, shall be covered through the collection of a fair, transparent and nondiscriminatory fee from ships. This cost recovery system comprises a built-in, fixed element and, possibly, a variable element according to the amount and type of waste actually delivered. Ferries and other ships in scheduled traffic may be exempted from mandatory delivery of waste at every port of call if the ship-owner or shipping company can show that waste is delivered and disposed of in a satisfactory way in a specified port along the ship's route.

6. Inspection and enforcement. Some of the ships should be inspected. If there are reasons to believe that it may cause pollution to the sea, a ship may be detained into the port until it has delivered its ship-generated waste and cargo residues to a port reception facility.

\section{References}

Europe Aid/130987/C/SER/AL: Technical Assistance for Strengthening the Capacity of the Ministry of Environment, Forests and Water Administration in Albania for Law Drafting and Enforcement of National Environmental Legislation.

M. K. Kersten (2010); MSc Thesis - Master plan Porto Romano Bay, Albania; Technical University of Delft, Department of Civil Engineering, Chair of Ports and Waterways.

http://repository.tudelft.nl/view/ir/uuid\%3A62a2387f-6652-49f6-9c7a-1ccc714056c3/

http://emsa.europa.eu/news-a-press-centre/external-news/2-news/1607-study-on-the-delivery-of-ship-generated-waste-and-cargoresidues-to-port-reception-facilities-in-eu-ports.html

http://ec.europa.eu/transport/modes/maritime/consultations/doc/prf/emsa-report.pdf

${ }^{3}$ Because ports are sources of considerable volumes of valuable wastes, one of the main subjects of local authorities dealing with urban sustainable development matters is ship and port waste management. 